\title{
FRIENDSHIP AS A NON-RELATIVE VIRTUE
}

\author{
Rachel Z. Friedman
}

$\longrightarrow$

7 HIS ARTICLE takes its bearings from Martha Nussbaum's "Non-Relative Virtues: An Aristotelian Approach," which argues that Aristotle's ethics tioning in which the various virtues are meant to represent excellent action. ${ }^{1}$ In calling attention to this important underlying feature of Aristotle's account, Nussbaum articulates a promising approach to the virtues that can accommodate cultural variations in their expression. The underlying spheres or "grounding experiences" that she identifies allow for the possibility of comparison among different accounts of what good action entails. Once such a sphere has been identified as the proper locus of the virtue in question, those who disagree about the appropriate ways of acting can be seen, not as talking past one another, but rather as "arguing about the same thing, and advancing competing specifications of the same virtue." ${ }^{2}$ A virtue ethics based on Aristotle's structure can thus remain grounded in human experience while also critiquing local customs in the name of "a more inclusive account of the circumstances of human life."

The aim of this article is to explore what such an approach to the virtues might look like in practice. To that end, it takes up the case study of friendship, the pinnacle of Aristotle's account of the ethical life. Friendship is a somewhat problematic virtue: Aristotle says it is a virtue or "involves virtue," and there is a strong case to be made that both claims are true. Nevertheless, it is a rich subject for study because, while a constant in nearly all human life, it is also subject to significant variation across and even within cultures (NE 1155a4). ${ }^{4}$ There has recently been a surge of scholarly interest in friendship and in Aristotle's account

1 Nussbaum, "Non-Relative Virtues."

2 Nussbaum, "Non-Relative Virtues," 247.

3 Nussbaum, "Non-Relative Virtues," 250.

4 All parenthetical references to Aristotle's Nicomachean Ethics ( $\mathrm{NE}$ ) are to the translation by Terence Irwin. My understanding of the NE has also benefitted from the translation of Robert C. Bartlett and Susan D. Collins. 
in particular. ${ }^{5}$ These analyses, however, typically do not address the question of whether Aristotle's model might be criticized in light of concerns about its cultural particularities and, if so, whether that model could be modified while remaining faithful to his basic framework. This article therefore aims, first, to show how alternative specifications of the same virtue may be put into fruitful dialogue with one another, contributing to an ongoing conversation about how best to characterize excellent action within a given sphere of human existence. Second, in so doing, it aspires to point the way toward a philosophical account of friendship that could bear fruit in contemporary life. ${ }^{6}$

The argument begins with what Nussbaum refers to as the "thin" definition of friendship. This is a definition that identifies the underlying sphere in which friendship constitutes excellent action. I conclude that the best candidate for this role is the sphere of association and argue that Aristotle in fact regards the best kind of friendship as representing the height of virtue within this realm. This step in the analysis isolates the basic human experience or need to which Aristotelian friendship responds and hence the role it plays in a flourishing life. With this in mind, section 2 takes up Aristotle's "thick" definition of friendship and argues that, in addition to encompassing the other virtues, complete friendship entails its own excellent action of sharing a life with someone equal and similar, and wishing her good as one would wish one's own. I expand on this point in section 3 by considering Aristotle's views on the relationship between friendship and erotic attraction. This issue is an important source of variation among accounts of friendship, in particular friendship of the closest and most exalted kind. Aristotle's views on the matter are typically principled and yet, I argue in section 4 , they also reflect the limitations of his cultural surroundings. The analysis therefore concludes by suggesting a modification to Aristotle's view-an alternative "thick" definition - that remains within the original thin specification while incorporating what I believe to be most lacking in his account, namely an erotic love of specific traits one finds in a friend as a form of mature longing for the good.

In combining a careful examination of Aristotle's arguments with an evaluation of their continued relevance, this article joins a chorus of scholars who

5 Recent contributions include Hope, "Friendship, Justice, and Aristotle"; McCoy, "Friendship and Moral Failure in Aristotle's Ethics"; Salkever, "Taking Friendship Seriously"; and Pangle, Aristotle and the Philosophy of Friendship. See also Stern-Gillet, Aristotle's Philosophy of Friendship; O'Connor, "Two Ideals of Friendship"; and Annas, "Plato and Aristotle on Friendship and Altruism."

6 In a similar spirit, Salkever also attempts to "bring Aristotle into conversation with ... modern conceptions of friendship," but he does not discuss the source of particularity that I identify here or engage at length with the modern alternative ("Taking Friendship Seriously," 70-75). 
have lately emphasized that studying the history of virtue ethics has value for contemporary moral philosophy. ${ }^{7}$ By placing Aristotle's views into conversation with our own, I hope to show that we have much to gain from engaging with alternative specifications of the virtues. In particular, this exercise can clarify the assumptions and aspirations that shape some of our own practices, and help us to better understand what is involved in choosing one account over another.

\section{SITUATING ARISTOTLE'S VIRTUE: THE “THIN” DEFINITION OF FRIENDSHIP}

To approach Aristotelian friendship as a virtue in a way faithful to Nussbaum's underlying-experience approach, we begin by looking for the basic sphere of human life in which friendship constitutes excellent action. The most obvious candidate for that sphere is association or sociability. ${ }^{8}$ Aristotle enumerates several social virtues in book IV of the Nicomachean Ethics, three of which are explicitly concerned with voluntary social interactions. Friendliness, which is the nameless virtue of accepting or objecting to the right things in the right way, "would seem to be most like friendship" (NE 1126b21). Truthfulness, the second social virtue, involves judging how to present one's own qualities. Finally, wit or grace describes the proper bearing in general company, and as such requires discrimination, taste, and the understanding that "different people find different things hateful or pleasant" (NE 1128a28). All three associational virtues are directed toward everyday dealings with acquaintances, not necessarily close family and friends. Close relations clearly involve a partiality or affection that is not present in friendliness alone. They also seem to point beyond truthfulness, insofar as they rely less on how individuals present themselves than on their characters as they really are. Finally, friends often develop a unique sensibility or way of spending time that might not be appreciated in general company but that brings them great pleasure and need not be uncivilized.

The Nicomachean Ethics famously provides another sustained discussion of

7 See Gardiner, "Virtue Ethics, Here and Now," as well as the other contributions to the same volume.

8 In referring to the sphere of association I follow Nussbaum's enumeration of the spheres and their corresponding virtues in her "Non-Relative Virtues," 246. Although I will not rehearse Nussbaum's responses to those who object to the notion of fundamental human spheres, I agree that association with other humans survives the most serious objections to the Aristotelian approach. It is very hard to deny that all humans have a need for contact with others and even some fellow-feeling toward them (although, as Aristotle recognized, the latter is often limited to their own "kind"). It is therefore safe to assume that some broad category of association is a universal feature of life, without which we would have difficulty conceiving of ourselves as human. 
what we might identify as the virtues of social interactions: this is the discussion of philia in books viII and Ix. Although typically rendered in English as friendship, philia is better translated as love or affection and is therefore broader than friendship as English speakers understand it. ${ }^{9}$ Despite the breadth of the subject matter, however, this discussion does not rely on the three aforementioned social virtues at all. This suggests that Aristotle intends to make a distinction between the virtues of casual sociability and the virtues of closer relationships. Indeed, a few differences between the two discussions are immediately apparent. First, while the virtues described earlier are relatively self-contained, Aristotle notes from the outset of his account of philia that it encompasses other virtues as well. Specifically, the best kind of philia encompasses justice, which Aristotle calls "complete virtue in relation to another" (NE 1129b27).$^{10}$ Complete friendship exists only to the extent that justice does, and indeed relies on justice or something like it (NE 1161a10, 1161a35, 1162a30-35, 1165a28-33). In fact, Aristotle says that friendship is the end of justice and that "if people are friends, they have no need of justice" (NE 1155a27) ${ }^{11}$ Friendship thus demands social excellence of a far-reaching sort while the earlier social virtues do not.

9 See Nussbaum, The Fragility of Goodness, 354, and Irwin's glossary entry on philia in his translation of the NE, 330. On the same subject, David Konstan argues that Greeks made a distinction between philia and philos, which he finds refers to friends in the narrower sense, but that they lacked a specific abstract term for "friendship." As a result, while one could say the equivalents of "friends" and "love" or "caring behavior," there was no specific word for the relationship between those whom we call friends (Konstan, "Greek Friendship," 74-78, 92). He provides further evidence for the narrower meaning of philos in his Friendship in the Classical World, 53 .

10 Aristotle's discussion of the first social virtues appears immediately before his account of justice, while his discussion of philia comes after it. In calling attention to the order of Aristotle's discussion, I rely in part on Irwin's claim that the order of treatment from the beginning of the NE through book IX is likely Aristotle's own. See Irwin, "Introduction," xvi.

11 Aristotle says that friendship renders justice unnecessary or is the highest form of it ( $N E$ 1155a28-29). These two claims appear to conflict with one another: either friendship renders justice unnecessary or friendship is justice. Delba Winthrop argues that in practice friendship is meant to supplement justice while in theory it is meant to replace it. That is, while the teaching on friendship "grounds in a more satisfactory way the institutions and habits which are necessary to ensure a modicum of justice," Aristotle never denies the necessity of justice because complete friendship is so rare (Winthrop, "Aristotle and Theories of Justice," 1214). This reading sheds light on Aristotle's seeming equivocation in the passage just quoted, since it suggests that, while friendship does render justice unnecessary from a theoretical point of view, in the complicated and problematic reality of human affairs justice must persist and friendship is its highest form, realizing its aims most fully while also pointing beyond it. Danielle Allen, writing primarily about political friendship, also points out that friendship both "achieves what justice does" and "extends beyond justice," in part because only friendship fully succeeds in converting rivalry into equity (Allen, Talking to Strangers, 121, 136). 
Furthermore, while each of the first three social virtues involves careful attention to the demands and potential reactions of others, the best kind of friendship relies on qualities that can be "found in the decent person's relation to himself" (NE 1166a10-11). ${ }^{12}$ Aristotle makes this claim immediately after relaying the opinion, which he goes on to endorse, that a friend is someone who "wishes and does goods or apparent goods to his friend for the friend's own sake," just as he wishes good things for himself ( $\left.N E 1166 \mathrm{a}_{3}\right)$. This suggests that, whatever friendship is, it goes deeper than the ability to act well toward others in isolated situations. A good friend knows how to be good to herself, without which she cannot know how to wish that same good for another. What seems at first glance to be a prime candidate for excellence within the sphere of sociability, then, has started to look more like excellence simply. While some forms of friendship are clearly possible without complete virtue, these are defined in reference to the best kind of friendship, in which both partners are excellent all around (NE 1166a12). The standard for friendship, then, is not virtue in one sphere of human life but rather depends on and manifests virtue in all the spheres. These points cast doubt on the correctness of identifying friendship as excellent action in the sphere of sociability.

There is also another difficulty involved in situating friendship in this way: namely, as A.W. Price puts it, that Aristotle presents philia not as a genus unifying its species but as a "range of relationships held together ... by reference to a single type."13 It is well known that Aristotle enumerates three kinds of friendship in both his Eudemian and his Nicomachean Ethics: that of utility, that of pleasure, and that of virtue. ${ }^{14}$ Yet it is not clear how exactly these three kinds of friendship relate to one another. According to Price's reading, Aristotle argues in the Eudemian Ethics for a focal relationship between the lesser kinds of friendship and the best or primary kind, but does not show how the former have enough in common with the latter to actually count as friendships; in the Nicomachean Ethics, by contrast, Aristotle offers more detail about the three kinds but is less explicit about the pattern into which they fit. ${ }^{15}$ On the positive side, this should enable us to focus on primary or complete friendship without trying to incorporate the lesser varieties into a rigorously systematic account. At the

12 See also NE 1157b34-1158a2, 1168b1-10.

13 Price, Love and Friendship in Plato and Aristotle, 131.

14 In the NE, Aristotle variously refers to the last kind of friendship as "complete friendship" (1156b7), "friendship primarily and fully" (1157a31), friendship "without qualification" (1157b4), "friendship of virtue" (1158b10), and the "best type" of friendship (1158b12). I will use these terms interchangeably and also follow the practice of some commentators of calling the best kind of friendship "character friendship." See, e.g., Sherman, "Aristotle on Friendship and the Shared Life.”

Price, Love and Friendship, 134-38. 
same time, however, it calls into question whether we will be justified in regarding complete friendship as the virtue of right action in the sphere of sociability. Because it means that the best kind of friendship is related only loosely to the two more common kinds, and even more loosely to philia broadly construed, it may be too specific and rare a phenomenon to deserve the single definition of right action in such a vast realm of experience.

These considerations might lead one to conclude that the "grounding experiences" approach is at once too narrow and too broad to apply to Aristotelian friendship. It is too narrow because to fit complete friendship into a single sphere risks denying its need to encompass all of the other virtues as well. At the same time, it is too broad because it expands the significance of such friendship across a wider realm of human experience than it may deserve. To the first objection, we can respond that there is no reason why friendship cannot both be a specifically social virtue and encompass the other virtues. As a grounding experience, sociability has the unique feature of permeating all aspects of our lives: without the ability to get along with others, it is simply not possible to live life well. Moreover, without others among whom to exercise one's virtues, in particular those such as generosity and justice, there is little reason to possess them in the first place. The idea that a virtue encompassing other virtues is also a fundamentally social virtue thus reminds us of the close connection between living well and living with others - not merely by tolerating or getting what one needs from them, but by appreciating their essential role in human happiness.

The second objection is somewhat more difficult to answer, because it points out that, in identifying friendship as right action within the sphere of sociability, we are limiting the heights of virtue within a very broad area of human life to the very few. Aristotle suggests that only those who are already virtuous can enjoy complete character friendship. The implication of this claim seems to be that everyone else is excluded from social excellence. Yet it is important to recall that possession of the virtues is not an all-or-nothing affair. Of course, to define excellence in a certain way is almost by definition to restrict its achievement to a relatively small number of people. Very few, if any, will be fully virtuous. Nevertheless, Aristotle tells us that many will be capable of some form of character friendship and therefore some degree of social excellence. At the beginning of his discussion in the $N E$, he says that complete friendship is rare because truly virtuous people are few $(1156 \mathrm{~b} 25)$. At the very end of his discussion, however, he notes that "the friendship of decent people is decent, and increases the more often they meet. And they seem to become still better from their activities and their mutual correction" (NE 1172a10-13). He thereby admits that even those who are not perfect can benefit from the salutary effects of character friendship, 
something that resembles the best kind even if it does not fully attain it. ${ }^{16} \mathrm{We}$ look to Aristotle's model, then, not in order to portray the world in binary terms of the perfectly virtuous and everyone else, but rather to flesh out an account of the heights of human achievement, to see what it might too hastily assume or leave out, and then to shape our own practices, to the best of our ability, in light of what we have found.

Nussbaum distinguishes between the "thin" or nominal definition of a virtue, which is "whatever being disposed to choose and respond well consists in" within a particular sphere, and the "thick" definition, which is the virtue's actual specification. ${ }^{17}$ We have now seen that producing a thin definition of the virtue of association is far from a simple task-in fact, there may not be a single thin definition at all. I therefore propose to regard the sphere of association as containing a number of phenomena of which complete friendship is one. Correspondingly, we will also have to see the virtue or virtues associated with Aristotle's complete friendship not as the only social excellence but as social excellence of a particular type, in fact the most elevated or desirable. The latter view finds support if we think of justice as the paradigmatic or most authoritative social virtue. ${ }^{18}$ Just as one might have an intuitive grasp of proper social conduct without being just, so too we can imagine someone who is just yet who does not know how to be a good friend. ${ }^{19}$

Having situated complete friendship in this way, we can begin to see what purpose it serves in Aristotle's account of a happy or flourishing life. Of all of the associations Aristotle discusses, complete friendship is the most choice-worthy: it serves at once the many functions that association is thought to serve-utility, pleasure, and most of all virtue-and it does so in the most lasting way possible. It therefore not only protects friends against misfortune and error, and provides them with a pleasant way to pass the time, but it also enables the continued exercise and development of their best desires and qualities. We will thus be able to place alternative accounts of friendship into a dialogue with Aristotle's if they too concern a partnership that does not merely address vital basic needs but also calls on and manifests the heights of both friends' humanity.

Price makes a similar point, arguing against a more pessimistic view advanced by John Cooper. Price notes that, just as human beings exist on a spectrum from very good to very bad, so too examples of character friendship may range from total to incomplete (Love and Friendship, 158).

17 Nussbaum, "Non-Relative Virtues," 247.

18 See also Nussbaum, The Fragility of Goodness, 351-52.

19 While lacking actual friends could be the result of bad luck, lacking the ability to be a good friend is far more likely a failure of character. 
The question we must now address is what particular excellence one needs in order to be capable of complete friendship on Aristotle's terms. This corresponds to Nussbaum's "thick" definition, the rich specification with which any alternative account will have to grapple. Price has ably set out and defended the view that the primary or best form of Aristotelian friendship is characterized by wishing one's friend well for her own sake, which distinguishes character friendship from the lesser forms of philia $^{20}$ Aristotle makes clear that one should have the same kind if not degree of concern for one's friend that one has for oneself. In addition, wishing a friend well requires more than merely having the right internal state; character friends must share in one another's activities, in particular the distinctively human activities that are constitutive of a good life. ${ }^{21}$ Following Price's analysis in significant respects, I will argue that complete friendship requires shared activity because through it each friend is able to reflect upon herself by observing and conversing with the other. ${ }^{22}$ This means that one's friend must partake of virtuous activity of the same sort and in the same way that one would wish for oneself, and that one will in turn desire the continued good of the friend just as one would desire one's own good. It is very important on this model that the friend be understood as an independent being capable of acting well on her own volition; otherwise, her action will reflect neither her own virtue nor, by extension, that of her friend. This vision of well-wishing depends on the excellence and relative self-sufficiency of both friends, features about which I will have more to say in the next section. What I wish to bring out here is that the ability to realize Aristotle's vision also requires the recognition that even the greatest excellence is incomplete without others with whom to share it.

Near the beginning of book vil of the Eudemian Ethics, Aristotle offers an initial description of the types of friendship and states several essential require-

The importance of friendship is, on Price's reading, largely epistemic: in joint deliberation and activity with one's friend, one comes to discover one's own self through the other. This process explains why even good people need friends, since to act virtuously requires being aware both of how an activity comes about and how it is performed. The friend's acting well in turn becomes a part of one's own happiness because one identifies with her choices. One wishes the friend to continue acting well in order to continue to know oneself and to persist in virtuous activity. For the detailed development of this argument, see Price, Love and Friendship, 120-24.

This point is also emphasized in Salkever, "Taking Friendship Seriously," esp. 68-69.

One difference is that I emphasize the pleasure of self-perception more than its instrumentality for virtue, but I also discuss the instrumental role of friendship, below. 
ments for friendship of the best or primary kind. ${ }^{23}$ First, such friends must mutually recognize each other's goodness of character, since it is on this recognition that their friendship is built (EE 1236b1-6). Second, they must feel mutual affection based on their respective goodness, not on any accidental qualities they possess (EE 1237a40-1237b5). Third, they must find shared purpose and agreement, which is possible because both friends aim at a conception of the good and have the constancy of character to pursue that conception over time (EE 1237b10-35). Fourth, a friend must not only be good absolutely but also good to another, which means actively sharing in the partnership and therefore precludes having a large number of friends (EE 1238a4-11). Finally, character friends are beneficial to another not with respect to any particular purpose, but rather for the unqualified good of each (EE 1238a30-1238b15).

These observations lead Aristotle to a discussion of equality in friendship and to the conclusion that friends of the best kind must be equal. In unequal friendships, reciprocity between the parties is lost, since a benefactor either does not return the affection of the benefited or does not return it in the same way. As a result, such friendships are prone to discord (EE 1239a5-20). By contrast, the aim of complete friendship is shared choice and virtuous activity, which is also pleasant by virtue of being good. This means that the friends must have the same motivations and purposes, which is not possible if what is good for one is not good for another. Moreover, activity consists more in loving than in being loved, so if friends are unequal in their affection their activity necessarily differs (EE 1237a35-4O). Inequality therefore leads to disharmony and to a reduction or loss of the shared activity that characterizes the best kind of friendship.

Aristotle has still not explained, however, why friendship must revolve around the kind of shared ends that equality makes possible. After discussing a number of other issues, he at last comes to the question of why, if happiness is self-sufficiency and the good human being is as self-sufficient as possible, such a person will nevertheless need or want friends. What human beings most desire, he says, is perception and knowledge, and in particular they desire perception and knowledge of themselves (EE 1244b25-1245a11). One attains this knowledge through a friend, who is one's other self. The friend must therefore reflect one's own characteristics and her ends must be one's own, since only then will one be able to observe oneself in observing the friend. It is pleasant to share even base pleasures with friends, but it is "more so to share in the more divine pleasures;

23 All parenthetical references to Aristotle's Eudemian Ethics (EE) are to the translation by Rackham, with cross-references to that of Inwood and Woolf. 
the reason of which is that it is always more pleasant to behold oneself enjoying the superior good" (EE 1245a35-40). ${ }^{24}$

Aristotle does not fully explain here why the goal of human life is self-knowledge or why such knowledge demands another person. Even if we grant that the virtuous person must know her own motivations in order to be fully good, the argument for friendship based on this claim is circular: humans need character friends in order to be virtuous, since without such friends they cannot fully know themselves, but they must be virtuous in order to have such friends. Perhaps this is why the following passages and Aristotle's discussion in the NE emphasize the pleasure more than the necessity of self-perception. On this account, happiness is activity, and perception or understanding is the definitive activity of human life (NE 1170a16-19). The activity of the good human being is excellent and pleasant in itself, so it is particularly pleasant for the good person to observe her own activity (NE 1169b29-33, 117ob1-6). Yet the activity of an excellent friend is just as pleasant, if not more so, since it is thought to be one's own, yet it is easier to observe another than to observe oneself (NE 1169b34-1170a2). The truly "blessed person" will therefore need virtuous friends in order to fully experience the pleasure of a virtuous life (NE 1170a3-4). ${ }^{25}$

Just before this passage in the NE, Aristotle offers another indication of the value of friendship to the already virtuous person. Here, he concludes a discussion of selfishness and self-love with the claim that a good friend must be a self-lover. Such a friend always pursues the noble or fine, including by forfeiting money or even actions for the benefit of friends, "since it may be finer to be responsible for his friend's doing the action than to do it himself” (NE 1169a34). In describing the self-lover in this way, Aristotle seems to recall that honor-loving paragon of virtue, the great-souled man. ${ }^{26}$ Yet there is reason to question whether the great-

24 Cooper, in reconstructing Aristotle's argument for the importance of friendship for the good life, relies heavily on another passage to very similar effect from the Magna Moralia $(M M)$. Yet this passage does not go much beyond the $E E$ insofar as the latter also emphasizes self-knowledge. Cooper stipulates that the self-knowledge obtained through friendship is knowledge "of what actually motivates one's actions, not just of what intellectualized theory of living one is prepared to defend" ("Aristotle on Friendship," 339n23). This argument does not fully explain why the virtuous person, who should already know what motivates him, needs another person to complete his virtue. See Cooper, "Aristotle on Friendship," 320-22.

25 A concise summary of the $E E$ and $N E$ arguments combined (along with that of the $M M$ ) is found in Sherman, "Aristotle on the Shared Life," 106.

In book III of the $E E$, Aristotle praises greatness of soul as a virtue that relies on all the other virtues (EE 1232a32-38). The one who possesses it has the best possible disposition toward those goods that most human beings desire, since of all of them he cares most for honor (EE 1232b10-12, 1233a4-7). Aristotle's account in the NE is similar: because "it is only the good person who is honorable," those who "lack virtue but have [the goods of fortune] 
souled individual is in fact capable of complete friendship. We cannot help but think of this character when, in book viI of the EE, Aristotle notes that those who are ambitious of honor tend most of all to seek friendship on the basis of superiority rather than equality ( $E E$ 1239a26). Some are by nature ambitious, while others are affectionate and prefer to love than be loved. The great-souled clearly belong in the first category. Of the two, however, Aristotle says that the one who loves is both more aware of the good that he possesses and more self-sufficient. He possesses the pleasure of loving simply by doing it, while "being loved is an accident, as one can be loved without knowing it" (EE 1239a33). ${ }^{27}$ To the extent that he shuns friendships of equality, then, someone who is primarily concerned with honor denies himself a significant part of the activity of friendship as well as the pleasure that accompanies a shared life.

While friendship is the culmination of the virtues, then, it also depends on the recognition that even the most virtuous life is radically incomplete without it. First, without friendship even the best person cannot fully exercise her virtues, in particular those such as generosity and justice that are oriented toward another. Second, she will lack an accurate view of her own activities through which to attain the pleasurable self-understanding that, according to Aristotle, distinguishes human life from other forms. Finally, she will lack an important source of trustworthy guidance for the ongoing activity of living well. ${ }^{28}$ Even the friendship of the best person will therefore be aimed at a good that is higher than what each partner brings individually, a good that neither can attain alone.

\section{COMPLETE FRIENDSHIP AND EROS}

My discussion has led to the conclusion that friendship for Aristotle both involves virtue and is a virtue itself: it is the excellent activity of sharing one's life with another, someone with whom one shares the perception of being worthy because similar and equal in goodness. We have thus fleshed out a good deal of Aristotle's "thick" definition of friendship. Yet it is worth highlighting a few features that will in turn provide focal points for the more critical analysis that fol-

are not justified in thinking themselves worthy of great things, and are not correctly called magnanimous; that is impossible without complete virtue" (NE 1124a25-29).

See also NE 1159a28.

28 Aristotle says in NE that we "enlist partners in deliberation on large issues when we distrust our own ability" to get the judgment right (1112b11). This could well be what he has in mind when he refers to a good person being guided by his friend (see 1125a1). This need not mean that person's judgment is otherwise faulty. Rather, as Sherman points out, the very act of choosing a friend exposes one's character and capacity for practical reason ("Aristotle on the Shared Life," 97). 
lows. Specifically, I would like to dwell on the role-or lack thereof-of eros in Aristotle's complete friendship, since this is among the central issues that divides accounts of friendship across cultures and time periods, and even within societies. ${ }^{29}$ Erotic relationships represent some of the most intense forms of voluntary association experienced by human beings, particularly in an era where time to associate meaningfully with those who are not lovers, life partners, or family members is limited. In fact, philoi who are bonded by some sort of erotic connection are today most likely to meet Aristotle's key criterion of living together, which ensures that friends will come to know one another's characters and allows them to share many of their activities. ${ }^{30}$ If Aristotelian friendship cannot be realized within such relationships, then, we will have come up against a serious challenge to the application of Aristotle's model in the contemporary world.

Price, after surveying Aristotle's scattered remarks on the subject, concludes that within both marriage and pederasty Aristotle "envisages the emergence of that reciprocal concern and respect which constitute the best kind of friendship. ${ }^{31}$ Even if Price is correct about this, I hope to show in what follows that to the extent that such a friendship might emerge, it would on Aristotle's account require a fundamental alteration of the nature of the original relationship. The reason for this is that Aristotle is reluctant if not altogether unwilling to regard intense desire and the perceived need to possess what one lacks as positive elements of friendship. His complete friendship is in fact best realized among those who feel no burning need at all—who are, rather, content with their characters and consequently able to accept the separate existence of their friends. ${ }^{32}$

In one of Aristotle's more direct statements about eros and friendship, found in the $E E$, he says that while eros seems to resemble philia because lovers desire to live together, they do so "not in the most proper way but in a sensuous manner" (EE 1245a25-26)..$^{33}$ Aristotle has just reported what he goes on to call the "facts

29 For instance, it is one of the questions distinguishing Aristotle's account from Plato's. See Annas, "Plato and Aristotle on Friendship and Altruism," 536-37. For a critique and modification of Plato's view, see Soble, "The Coherence of Love."

30 For a discussion of his requirement, see Nussbaum, The Fragility of Goodness, 358-59. Nussbaum suggests that had Aristotle not believed in the inferiority of women "he would very likely have preferred this sharing [of activity among friends] to extend to the sphere of the household as well [as the polis]: thus an even more perfect philia would be a good marriage, in which the full range of the aspirations and concerns that make up a human life might be accommodated" (The Fragility of Goodness, 358). I will have more to say on this subject below. Price, Love and Friendship, 249. See also Nussbaum, The Fragility of Goodness, 356. Price notes the lexical and syntactic ambiguity of this statement, which can mean either that the lover, unlike the friend, desires not to benefit the beloved but to enjoy seeing him, 
of experience" about sociability, namely, that all people find it pleasant "to share good things with our friends, as far as these fall to each, and the best that each can" (EE 1245a21-22). Most likely, then, Aristotle's criticism of the partnership of lovers is that what they desire to share in their lives together is not the highest possible good but rather the sensuous good of physical contact. As a consequence, such friends will not attain what Aristotle immediately goes on to identify as the greatest benefit of friendship. While it may be the case that sensual pleasure is the most some people are capable of sharing, the implication of this discussion is that such people nevertheless do not attain complete friendship, and that those who stop here despite being capable of sharing more are not fully realizing their potential.

It may be the case that for Aristotle two friends who choose to pursue physical pleasure in addition to sharing a life of the finest goods can do so without compromising the nature of their friendship. Yet there is another aspect to Aristotelian love, aside from the appetitive or pleasure-seeking side-namely, erotic emotion that adores its object. We must therefore ask about the case of a friendship in which part of the highest good that both friends share is the erotic adoration of what the other possesses, perceived as something that each individually lacks. It is not clear that Aristotle regards the latter as a legitimate part of complete friendship. In fact, there is reason to think that erotic longing of this sort hinders rather than furthers such friendship. Aristotle notes in the EE that opposites desire one another because they desire the mean to which their opposite brings them (EE 1239b24-124Oa4). In this sense, such love of the opposite is love of the good, since each recognizes what she lacks and strives through the other to obtain it. Yet unlike the virtuous person, who desires what is simply good, those who love their opposite only want what "takes them outside their natural state" (EE 1239a39). As if they were too hot or too cold, they look to the other to relieve them from the discomfort of the extreme. ${ }^{34}$ This passage captures well the sense of neediness and even pain that lovers feel in the absence of their beloved. Indeed, in the NE, Aristotle likens erotic passion to an excess, and in the Politics he likens Socrates' proposal that the city be made one to Aristophanes' account in Plato's Symposium of lovers who "from an excess of affection" desire so much to

or that the lover's approach is dictated not by choice but by physical desire. Price, Love and Friendship, 240-41.

34 Aristotle relates a similar view in the $N E$, particularly in discussing Euripedes' claim that when the earth is dry "it longs passionately for rain," and the heaven in turn when filled with water "longs passionately to fall into the earth" (NE 1155 b2-5). Aristotle goes on to identify erotic friendships among the young with friendships of pleasure and to note that it is their passion that makes their friendships so fleeting (NE 1156b1-4). While Aristotle perhaps intends to refer here to mere sexual appetite, this comment is consistent with other remarks in NE about the instability of erotic relationships (see NE 1157a8-10). 
grow close that they fuse together, causing one or both to disappear (NE 1158a13; Politics 1262b10-15). ${ }^{35}$ This last passage distinguishes between the erotic attachment of the lovers and the fellow feeling that holds a city together. In the case of the lovers, excess desire for the other causes each to forget the good; in the case of the city, the danger is not an excess of desire but the denial of affection altogether. Despite their differences, however, both cases suggest that if humans are to achieve healthy relationships, they will have to respect the fact that those they hold dear have separate existences. Such recognition allows each partner to pursue her own good rather than static unity with the other, and to perceive the friend as precious because subject to various forces beyond her own control. ${ }^{36}$

This concern about the denial of separateness may also be why Aristotle says in the $N E$ that an "extreme degree of friendship" resembles friendship to oneself-that is, it takes the other as an extension of one's own will, subject to one's control (NE 1166 b1-2). The danger of eros for Aristotle seems to be that, in its overpowering need, it threatens to spur the lover to seek an unrealistic command over fortune and to substitute concern for the beloved's true good with concern for his own needs or desires. ${ }^{37}$ Aristotle does suggest that erotic friendships may become character friendship: in the $N E$, he notes that while pederasty involves contrary pleasures, many such lovers "remain friends if they have similar characters and come to be fond of each other's characters from being accustomed to them." Yet he makes it clear that this shift takes place "when the beloved's bloom is fading," and hence when eros gives way to affection rooted in time spent together and the mutual appreciation of character (NE 1157a8-12)..$^{38}$

If we return now to some of the key features of Aristotle's complete friendship,

35 References to Aristotle's Politics are primarily to the translation by Lord, with cross-reference made to that of Jowett.

36 Aristotle concludes this passage of Politics with the remark that two things above all make human beings cherish and feel affection: that something is their own and that it is precious. This passage is intended as a criticism of a city that denies individuals their separate kin and possessions. Yet we can also interpret the second requirement as referring to the necessary separateness and hence fragility of the lives of those for whom we feel affection. We are more apt to consider someone or something as precious if we recognize the degree to which forces outside of our control can take it away from us. I am indebted in my thinking on this last point to the discussion of Aristotelian friendship in Nussbaum, The Fragility of Goodness, 354-69.

37 Nussbaum notes that the accounts of unreformed love in Plato's Symposium reflect a general cultural view of eros as tied not with mutuality but rather with a longing for the possession of something "seen as valuable and urgently needed" (Upheavals of Thought, 483).

38 Aristotle's view seems to refer to pederasty as it was commonly practiced at his time. On the inequality of the relationship and the different emotions of the two partners, including in the act of intercourse itself, see Dover, Greek Homosexuality, 52, 84, and 91. 
we can see clearly that the neediness and longing of eros do not play noticeable roles. First, complete friends should be equal and similar, drawn together not by desire but by the appreciation of one another's goodness. Second, Aristotle assumes character friends will be more or less completely virtuous. This means that they do not feel a need for one other so much as they find that the other makes life more pleasant. It is not difficult to see why character friendship works best among those who are each excellent in this way. Within a friendship of virtue, I will not seek to control the actions of my friend, since in doing so I deprive her of her own virtue and therefore of the reflection she provides of mine. In order to resist this temptation, however, I will have to feel confident that she can and will act in the way that I would wish for her, and that my wishes for her are in fact aligned with her good. In other words, I have to genuinely be able to wish for her to live in a way that is good for her, and to realize that my own benefit is a derivative thereof. A friendship that is motivated by the sense of privation will likely never reach this mature state, since the one who desires will continue to seek through his friend the direct fulfillment of his own needs.

Aristotle's assumption of goodness and concomitant self-sufficiency does not, as I have already pointed out, exclude the possibility of character friendship among the decent but less than excellent. Aristotle even suggests at one point that character friends might complement one another, since each may possess different qualities and "it is difficult for all to be realized in the case of one person" (EE 1245a30-31). ${ }^{39}$ Nancy Sherman takes this statement to support an argument for the importance of complementarity and emulation in Aristotelian friendship. Although neither friend may be perfectly virtuous, each will be inspired to develop his character more fully as he sees admirable qualities in the other. ${ }^{40}$

I have suggested that this view does not completely reflect Aristotle's understanding of character friendship, which denotes the rare excellence of the fully virtuous and not such (more accessible) striving. ${ }^{41}$ It is also noteworthy that Aristotle devotes little attention to the particular motivations and challenges of character friendship among those who have not attained the standard or may not be fully capable of doing so. This means that he declines to address a significant part of the experience of friendship for those of us who seek close friends not only so that we may perceive ourselves in someone similar, but also for the challenge and self-correction that can accompany a close encounter with ways of thought and being that are significantly different from our own. In other words, Aristotle does not fully account for the intense experiences of desire, self-criti-

Cf. NE 1172a10-14.

Sherman, "Aristotle on the Shared Life," 105.

See NE 1156b25. 
cism, and striving that can come from the development and long-term continuation of a character friendship among those similar yet also deeply different, who share enough to understand and love one another yet whose distinct virtues and takes on the world exist in a perpetual and-ideally-productive tension. One kind of friendship that is likely to exhibit these features is that between longterm romantic partners or spouses.

\section{MODERN "COMPANIONATE" MARRIAGE:}

A MODIFICATION OF ARISTOTELIAN FRIENDSHIP?

We have just seen that there is a tension for Aristotle between eros and the best kind of friendship. While erotic love may indeed turn into character friendship, thanks to the familiarity that time spent together brings, by then it will have transformed into a different kind of association, one in which the friends no longer feel they intensely need one another. If this conclusion is correct, it will have implications for Aristotle's positions concerning pederasty on one hand and companionate marriage or long-term erotic partnership on the other.

It is quite possible that Aristotle's apparent rejection of pederasty-which is not the same as a rejection of all homosexual eros-stems from his views about the role of desire in friendship rather than from the influence of entrenched sexual prejudice. ${ }^{42}$ Yet these same views, as principled as they may be, might have differed had Aristotle lived in a society where women were able to more fully develop their potential. That is, he might have found a more positive role for eros in friendship had he encountered women who could be the objects not only of male physical desire but of ethical and intellectual desire as well. In that case he may have had to grapple more deeply with the experiences just described, name-

Nussbaum has argued that Aristotle's apparent lack of interest in the eroticism of homosexuality-demonstrated by his decision not to include it in his survey of opinions about philia-is an injustice both to his method and to his friend Plato, whose lifestyle he might have seriously considered as a way of pursuing the good. That even such a fair-minded man could commit such an oversight is, Nussbaum submits, reflective of the "tremendous power of sexual convention and sexual prejudice in shaping a view of the world" (The Fragility of Goodness, 371). While Nussbaum is clearly right that Aristotle's own method requires the careful consideration of human alternatives, it is not obvious that we must read his reticence on the subject of homosexual eros as a prejudiced rejection of Plato or lack of interest in his way of life. Aristotle does not affirmatively exclude sexual relations from the best friendship, and given that such friendship would on his view have to exist between two men, we may surmise that he at least contemplated the possibility that their shared activity would include sexual relations. To the extent that Aristotle does diverge from Plato's views on eros, I have tried to suggest that the divergence is principled, though by no means immune to critique. 
ly, of appreciating the goodness in another who is equal in moral capacity and yet distinct in potentially profound ways. ${ }^{43}$

Aristotle does allow in the NE that the friendship between husband and wife may be a friendship of virtue, if both partners are decent. Children, who constitute a common good between them, may also help to render their partnership lasting (NE 1162a25-29). Yet Aristotle also makes clear that husbands should rule their wives in a political or aristocratic fashion, because men are naturally more suited to ruling, and that the nature of virtue differs for men and for women (Politics 1259a40-1259b9, 1260a1-10). He also suggests that the common good of raising children is not in fact equally shared, since women tend to feel they have labored more for their children and therefore to have more affection for them than men (EE 1241b4-9). A further limitation of marital friendship as compared with complete friendship for Aristotle is that Athenian men participated together in political and philosophical activities completely off-limits to their wives, activities that Aristotle was not alone in considering more reflective of virtue than housekeeping and childrearing. His views about the partnership between husband and wife were necessarily shaped, then, by his way of life and in particular by the externally imposed limitations of the women he saw around him. ${ }^{44}$

My point here is not simply that Aristotle might have included marital friendship as a species of primary friendship had he held different views about women. Rather, I wish to go one step further and suggest that had Aristotle been able to better appreciate women's intellectual and moral capabilities, he might have actually modified his views about primary friendship so as to allow a greater role for the erotic emotion of desiring what one lacks as a way of desiring the good. This need not mean adopting a view of eros as an inarticulate desire for fusion of the kind described by Aristophanes. Aristotle's sensitive concern for the independent good of the beloved would rightly rule out such an account. Nor would it mean denying the fundamental importance for complete friendship of a shared conception of the good. It would, however, mandate addressing the key features and dangers of this kind of relationship in a way that Aristotle does not.

It is not my intention to exclude from this characterization the friendship of long-term lovers of the same sex. Rather, I have chosen to focus on heterosexual eros as a prominent but nonexclusive example of a type of longing for a person who is different in significant respects, and which therefore offers a meaningful challenge to the Aristotelian view.

44 Because Aristotle's philosophical method is built on critical examination of traditional opinions, one should not be too quick to accuse him of unthinkingly accepting Athenian prejudices in this or any other regard. Nevertheless, his failure to seriously engage with the kind of long-term erotic relationship I have described does provide evidence that his understanding of friendship was limited by the possibilities for human life, and in particular women's development, revealed to him by his surroundings. 
Before I try to identify and address some of those issues here, it is worth noting that Aristotle's theory is more disposed than many others in the history of Western thought to endorse the type of mature erotic relationship I have described. He already accepts some of the distinctive qualities of erotic love, such as particular concern for one individual over others, the relative eclipse of generalized social concern by exclusive attachments, and the independence and mortality of the friend, whose vulnerability represents a potentially destabilizing factor in one's own life. ${ }^{45}$ It is therefore plausible that Aristotle would have been willing to incorporate a mature eroticism into his theory had he been able to imagine a relationship of equality and shared activity between spouses of different genders.

In order to situate such an alternative "thick" account within the same conversation as Aristotle's, however, we must first determine that this vision is as complete and choice-worthy as Aristotle understands character friendship to be. We must therefore address several dangers to which such a mature erotic relationship could, from an Aristotelian perspective, be prone. If the following criticisms are apt, we may not have found in long-term erotic partnerships a "thick" model comparable to Aristotle's character friendship.

The central danger for long-term erotic partnership from an Aristotelian perspective is that it will render the friends self-satisfied, complacent, and insular. First, in partnering with someone who possesses what one lacks, one may no longer feel a desire to cultivate those qualities for oneself. Rather than spurring self-correction and development, then, such a relationship could actually hinder those things, allowing friends to become mutually dependent. On a practical level, one sees this tendency at work in the entrenched division of household labor among some spouses, which not only discourages each from developing abilities possessed by the other, but also represents a significant amount of time that they spend in separate rather than shared pleasurable activity. Such an observation might even lead us to conclude that the spousal relationship is more an answer to our physical needs than a means to cultivate our ethical and intellectual capacities.

This concern could be addressed, however, by focusing on the partners' expectations, including and in particular their preconceived roles. If one partner believes that the most he can accomplish is to serve as a complement to his spouse, he will likely rest content with partial virtue and dependence. Yet if he enters into the friendship with an understanding of both his own strengths and of his potential for improvement, he will be more likely to continue pursuing a complete account of virtue, aided by the example and encouragement of his

45 For these criteria, see Nussbaum, Upheavals of Thought, 461, 470. 
partner. He will also be more likely to seek out the kind of shared activity that only two equals can enjoy. ${ }^{46}$

There is, however, another psychological temptation that may be more difficult to combat. Partners who believe that they have discovered the key to fulfillment in their complementarity may devote themselves excessively to one another and to the small world they have created, to the exclusion of engagement with their wider surroundings. ${ }^{47}$ Indeed, they might accept one another so completely that they lose the ability to reflect critically on themselves and-insofar as reflecting on one's own choices is a prerequisite for reflection in general-on the human condition. Stephen Salkever argues that the danger of erotic love on Aristotle's account is precisely that it is "unconditional, a quality that blinds us to the inevitable imperfections of composite beings such as we." Such love overwhelms our capacity for reasoned judgment and makes us forget the inherent limitations of human beings, a crucial spur to the shared activity of reflection. ${ }^{48}$

While I do not believe that this concern vitiates the model I am proposing, it does reveal a genuine tension between the wish for security and the drive for continued ethical and intellectual development. Robert Solomon points out that the embrace of another's particularities promotes "long-term care and passionate benevolence" toward that person, an important feature of mature erotic and spousal friendships. ${ }^{49}$ One would not wish to deny the power, and indeed the beauty, of such benevolence. Yet unconditional acceptance is at odds with the longing that, I have suggested, justifies considering this form of friendship as a model in the first place. If what one seeks in such unions is the productive

The question of how spouses can be said to share activity when they may have different occupations and life goals is an important one that I do not have space to fully explore. Briefly, I think it is important to distinguish between the highest good of a partnership and incidental goods that the partners may or may not share. As long as we do this, we can allow that partners will have very different occupations, provided they are able to take part together in what they understand as the most important or desirable activity of their lives. For some, this will be raising a child. (On this subject, in fact, Aristotle unwittingly provides an argument for the equal sharing of childrearing activities.) For others, it will be political or charitable engagement, artistic creation, or philosophic conversation. Obviously, this assumes a certain amount of free time to spend together, which may be unavailable or less than optimally available for families in which both spouses work multiple jobs outside the home.

47 Such a partnership would become static and stale, like Aristophanes' lovers welded together by Hephaestus. Nussbaum provides a vivid description of this eventuality: "Wrapped in each other's arms, there they lie, for the rest of their lives and on into death, welded into one, immobile" (The Fragility of Goodness, 176).

Salkever, "Taking Friendship Seriously," 73.

Solomon, "Erotic Love as a Moral Virtue," 99. 
tension of critical self-reflection and growth, then one may well worry that unquestioned loyalty will hinder rather than promote those ends.

We may be able to address this concern, in part, by modifying our expectations of unconditionality in long-term erotic unions. The sense of being loved as unique, even irreplaceable individuals seems to be an important aspect of what we seek out in such relationships. As Alan Soble points out, however, it is possible to understand erotic love as directed toward the beloved's good qualities without denying that one loves a particular person. In fact, to the extent that such qualities are constitutive of the beloved's identity, there may be no meaningful difference between loving the qualities and loving her. ${ }^{50}$ There is also nothing inherently more stable about love for an individual's quirks or particularities than for her virtues. As Soble puts it, "no matter what love is based on, love can be only as constant as its basis." ${ }^{51}$ Unconditionality may therefore not be as necessary to the fulfillment of our hopes as it appears at first blush.

In addition, focusing on the process of reciprocal improvement that, in the best case, characterizes such partnerships should alleviate the worry that someone who is loved primarily for his virtues is fungible with others who possess the same traits. Shared deliberation and mutual correction can generate a special kind of affection, grounded in the feeling that one has played a role in the other's development. ${ }^{52}$ Erotic partners may therefore grow more attached to one another through the perception that they are responsible for each other's characters, as well as through appreciation of the other's contributions to their own self-understanding. ${ }^{53}$

Above all, perhaps, we should remain clear-eyed about our motivations for entering into such friendships, and in particular about the possibility of competing desires. We may certainly cultivate affection for the traits that render our partner unique, particularly insofar as this helps to sustain our care and commitment over the long term. Yet we should distinguish, within ourselves, between the dispositions that promote compassion and acceptance and those that reflect our desire for critical engagement and growth. We should also prepare ourselves for the possibility that the two may not always coexist in harmony.

50 Soble, "The Coherence of Love," 299.

51 Soble, "The Coherence of Love," 306.

52 See also Milgram, "Aristotle on Making Other Selves." While I have not presented this argument as central to Aristotle's account of character friendship, I do think that it helps to alleviate the concern that the type of erotic relationship I am describing is less secure than one that prioritizes unconditionality.

53 Simon Keller makes a related point in emphasizing the dynamic character of romantic relationships and the fact that long-term partners take on new values and goals through their experiences together ("How Do I Love Thee?" 170). 
Finally, one might worry that introducing committed partnership or marriage into our account of friendship would threaten the Aristotelian vision of voluntary association, locking people into a union that may not serve the good of each individually. Perhaps one was initially mistaken about the virtues one most needed to cultivate, or selected a spouse based on an incorrect idea of the good. Perhaps one's partner has taken a turn for the worse, giving in to extreme tendencies in her personality or manifesting vices that were not evident before the friendship began. Marina Berzins McCoy notes that Aristotle recognizes a duty to assist a friend whose character has become compromised, at least if such vice is not incurable. Yet, as she also acknowledges, Aristotle accepts that "it might be necessary for the sake of one's own flourishing to end a relationship with another who threatens it-even a former friend." ${ }^{44}$ The ideal of loyalty that is part of our view of companionate marriage or committed erotic partnership would seem to preclude dissolving the friendship even in the face of such a threat - unless it was truly severe and long lasting, by which time the loyal friend may already have been harmed in some way. ${ }^{55}$

At the same time, committed partnership serves a purpose that many contemporary writers on friendship have found to be important. For example, Amélie Rorty argues that the modern view of life as one fashioned by ourselves alone leads to a strong sense of vulnerability, which we look to the continuous devotion of a friend to mitigate. Committed partnership is more likely than casual friendship or even Aristotelian character friendship to meet this psychological need, particularly given our fear that we may lose our best traits. Such friendship provides the modern individual — vulnerable, poorly understood, and in need of sympathetic acceptance - the lasting companionship of someone who steadfastly supports her. ${ }^{56}$ Given the fast pace of contemporary life and the high degree of geographic mobility, marriage or its behavioral equivalent may be our best hope

54 McCoy, "Friendship and Moral Failure," 150. O'Connor also notes that the modern ideal of intimacy could reinforce a friendship aimed at low ends, and in this sense have a negative influence on both friends ("Two Ideals of Friendship," 120).

55 Pangle notes that, on Aristotle's view, it is unlikely that friends who start out as virtuous will severely decline, since "virtue is by nature a stable thing, resting not only on deeply ingrained habits but also on clear and unshakable insights" (Aristotle and the Philosophy of Friendship, 138). This prospect appears more likely on the view I have proposed, however, according to which friends seek one another out based on the perception that they are not yet completely virtuous and the perceived need to learn from one other.

56 Rorty, “The Historicity of Psychological Attitudes," 80-83. O’Connor also stresses the "relief of our loneliness and support of our sense of self-worth" provided by modern intimate relationships, in contrast to the Aristotelian model ("Two Ideals of Friendship," 111). 
of approximating the sustained voluntary life sharing that Aristotle had in mind, enabling us to strive for the good while providing the security we need.

\section{CONCLUSION: FRIENDSHIP AND DIALOGUE ABOUT THE VIRTUES}

This article has set out to illustrate how, using Nussbaum's underlying-experience approach, a cross-cultural dialogue about the virtues might take place. Admittedly, my own critique of Aristotle's account is limited, and it is in some sense carried out from within his cultural and intellectual tradition. Nevertheless, it demonstrates a promising approach that may be applied more broadly in the future. First, by specifying the universal sphere of experience underlying the virtue of friendship, we were able to identify its function within that sphere and its role in a flourishing life more broadly. We were then able to consider Aristotle's full account and to identify one area in which his own cultural circumstances shaped and arguably limited his conception. Although proposing to modify Aristotle's thick definition, I preserved the thin account of friendship as fulfilling not merely basic needs but also a deeper longing to realize the best in ourselves by sharing our life with another.

I have suggested that Aristotle's reluctance to incorporate mature erotic longing into the best kind of friendship is attributable, at least in part, to the cultural particularities of women's role in ancient Athens. In proposing an alternative model based on a different understanding of women's abilities and social roles, however, I have opened myself up to the same charge of cultural particularism. It would appear, in fact, that the friendship I am proposing is based on a snapshot of contemporary liberal democratic life, or at least a certain sliver of it. In particular, it assumes equal opportunities for men and women in education, moral development, and the pursuit of fulfilling activities. It also assumes that individuals will have the resources and wherewithal to enter into their partnership voluntarily and out of love for the other's traits, not under pressure from external forces such as familial expectations, financial hardships, or other forms of dependency. As a result of these features, among others, the ideal of complete friendship among spouses is not one that is widely shared across cultures. ${ }^{57}$

57 In his sweeping study of English marriage from 1300 to 1840, Alan Macfarlane relies on anthropological research to argue that the Western ideal of "companionate marriage" is unusual. Elsewhere, he claims, the worlds of men and women are more or less separate, with women sharing their time and interests with female kin and neighbors and men doing the same with male associates. The Malthusian marriage system in England that Macfarlane takes as his subject was based on the ideal of a deep bond between husband and wife, yet as late as the eighteenth century it was considered unusual even in nearby France. See Macfarlane, Marriage and Love in England, 154-56. 
To some extent, the particularity of my own "thick" account is unavoidable. Yet what I am suggesting does go against the grain of some contemporary thinking on friendship in that it prioritizes not self-disclosure or emotional support, as important as these are, but rather shared activity for the exercise and further development of the virtues..$^{58}$ Deeper than that, my account also assumes that the traits to which we are primarily attracted in a partner-those that justify the partnership, if not holding it together through time-are identifiable and repeatable rather than wholly unique to that individual. In this regard, what I have proposed remains at least in part Aristotelian despite its otherwise modern assumptions. ${ }^{59}$ Finally, my account is broadly Aristotelian in that it has tried to remain true to his primary specification of friendship as excellent activity within a partnership that most fully expresses each friend's character and potential-in other words, to the idea of friendship as a shared pursuit of the good.

Although my account and Aristotle's are close cousins, they nevertheless challenge one another in valuable ways. For example, it is possible that our hopes for long-term erotic partnerships are in tension, insofar as we choose our partners for their repeatable virtues but seek to be loved for our own particularities. Confronting Aristotle's alternative can open our eyes to such difficulties. It also throws into relief some of our understandable and legitimate reasons for seeking out this combination of features in our closest friendships.

Of course, the alternative specification of friendship that I have offered here can and should be challenged by others wishing to articulate different ways of approaching the same underlying experience. Perhaps some will feel that my account is still too Aristotelian, others that it is too exclusive or individualistic. Regardless, I hope to have shown that the analytic framework at work here has the potential to generate important and productive debates, and that the thoughts in this article will ultimately contribute thereto. ${ }^{60}$

Tel Aviv University rachelf3@tauex.tau.ac.il

The Aristotelian "mirror" view and the modern "secrets" view are succinctly contrasted in Pahl, On Friendship, 80-87; and critiqued in Cocking and Kennett, "Friendship and the Self." See also Konstan, Friendship in the Classical World, 14-18, which argues that, while frankness and candor were valued in antiquity, in particular because they distinguished true friends from mere flatterers, the ancients did not value the revelation of intimate details about one's life as part of friendship.

On this point, compare Langer, Perfect Friendship, 114, with Nussbaum, The Fragility of Goodness, 306.

The author wishes to thank Martha Nussbaum, Anna Schmidt, and two anonymous peer 


\section{REFERENCES}

Allen, Danielle S. Talking to Strangers: Anxieties of Citizenship since Brown v. Board of Education. Chicago: University of Chicago Press, 2004.

Annas, Julia. "Plato and Aristotle on Friendship and Altruism." Mind 86, no. 344 (October 1977): 532-54.

Aristotle. Eudemian Ethics. Translated by Brad Inwood and Raphael Woolf. Cambridge: Cambridge University Press, 2013.

- Eudemian Ethics. Translated by H. Rackham. Cambridge, MA: Loeb Classical Library of Harvard University Press, 1935.

- Nicomachean Ethics. Translated by Robert C. Bartlett and Susan D. Collins. Chicago: University of Chicago Press, 2011.

- Nicomachean Ethics. Translated by Terence Irwin. Indianapolis: Hackett, 1999 .

- Nicomachean Ethics Translated by H. Rackham. Cambridge, MA: Loeb Classical Library of Harvard University Press, 1926.

- Politics. Translated by Benjamin Jowett. Princeton: Princeton University Press, 1984 .

- Politics. Translated by Carnes Lord. Chicago: University of Chicago Press, 1984.

- Politics. Translated by H. Rackham. Cambridge, MA: Loeb Classical Library of Harvard University Press, 1932.

Cocking, Dean, and Jeanette Kennett. "Friendship and the Self." Ethics 108, no. 3 (April 1998): 502-27.

Cooper, John M. "Aristotle on Friendship." In Essays on Aristotle's Ethics, edited by Amélie Oksenberg Rorty, 301-40. Berkeley, CA: University of California Press, 1980.

Dover, K.J. Greek Homosexuality. Cambridge, MA: Harvard University Press, 1978.

Gardiner, Stephen M. "Virtue Ethics, Here and Now." In Virtue Ethics, Old and New, edited by Stephen M. Gardiner, 1-7. Ithaca, NY: Cornell University Press, 2018.

Hope, Simon. "Friendship, Justice, and Aristotle: Some Reasons to Be Skeptical." Res Publica 19, no. 1 (2013): 37-51.

Irwin, Terence, trans. "Introduction." Nicomachean Ethics, xiii-xxviii. Indianapolis: Hackett, 1999. 
Keller, Simon. "How Do I Love Thee? Let Me Count the Properties." American Philosophical Quarterly 37, no. 2 (April 2000): 163-73.

Konstan, David. "Before Jealousy." In Envy, Spite, and Jealousy: The Rivalrous

Emotions in Ancient Greece, edited by David Konstan and N. Keith Rutter. Edinburgh: Edinburgh University Press, 2003. . "Greek Friendship." American Journal of Philology 117, no. 1 (1996): 71-94.

Langer, Ullrich. Perfect Friendship: Studies in Literature and Moral Philosophy from Boccaccio to Corneille. Geneva: Librairie Droz, 1994.

Macfarlane, Alan. Marriage and Love in England: Modes of Reproduction 13001840. Oxford: Basil Blackwell, 1986.

McCoy, Marina Berzins. Wounded Heroes: Vulnerability as a Virtue in Ancient Greek Literature and Philosophy. Oxford: Oxford University Press, 2013.

Milgram, Elijah. "Aristotle on Making Other Selves." Canadian Journal of Philosophy 17, no. 2 (June 1987): 361-76.

Nussbaum, Martha C. The Fragility of Goodness. Cambridge: Cambridge University Press, 1986.

. "Non-Relative Virtues: An Aristotelian Approach." In The Quality of Life, Vol. II: Traditions, Relativism, and Objectivity, edited by Martha Nussbaum and Amartya Sen, 242-69. Oxford: Oxford University Press, 1993.

- Upheavals of Thought: The Intelligence of Emotions. Cambridge: Cambridge University Press, 2001.

O’Connor, David K. “Two Ideals of Friendship." History of Philosophy Quarterly 7, no. 2 (April 1990): 109-22.

Pahl, Ray. On Friendship. Cambridge: Polity Press, 2000.

Pangle, Lorraine Smith. Aristotle and the Philosophy of Friendship. Cambridge: Cambridge University Press, 2002.

Price, A.W. Love and Friendship in Plato and Aristotle. Oxford: Clarendon Press, 1989.

Rorty, Amélie O. "The Historicity of Psychological Attitudes: Love Is Not Love Which Alters Not When It Alteration Finds." In Friendship: A Philosophical Reader, edited by Neera Kapur Badhwar, 73-88. Ithaca, NY: Cornell University Press, 1993.

Salkever, Stephen. "Taking Friendship Seriously: Aristotle on the Place(s) of Philia in Human Life." In Friendship and Politics: Essays in Political Thought, edited by John Von Heyking and Richard Avramenko, 53-83. Notre Dame, IN: University of Notre Dame Press, 2008.

Sherman, Nancy. "Aristotle on Friendship and the Shared Life." Philosophy and Phenomenological Research 47, no. 4 (June 1987): 589-613. . "Aristotle on the Shared Life." In Friendship: A Philosophical Reader, ed- 
ited by Neera Kapur Badhwar, 91-107. Ithaca, NY: Cornell University Press, 1993.

Soble, Alan. "The Coherence of Love." Philosophy and Theology 12, no. 2 (2000): 293-315.

Solomon, Robert C. "Erotic Love as a Moral Virtue." In Virtue Ethics, Old and New, edited by Stephen M. Gardiner, 81-100. Ithaca, NY: Cornell University Press, 2018.

Stern-Gillet, Suzanne. Aristotle's Philosophy of Friendship. Albany, NY: State University of New York Press, 1995.

Winthrop, Delba. "Aristotle and Theories of Justice." American Political Science Review 72, no. 4 (December 1978): 1201-16. 